\title{
Société des Africanistes: Centre de Documentation et d'Information
}

THE first number of the new quarterly Bulletin d'Information of the Centre de Documentation et d'Information of the Sociéte des Africanistes appeared in June 1964, under the editorship of Dr. Léon Pales, the Director of the Centre, and Mme Roberte Hamayon of CNRS. In his Introduction Dr. Pales explains how the committee of the Société des Africanistes decided to establish the centre at the Musée de l'Homme, and to make the results of researches more widely known by means of a regular periodical.

The area covered by the documentation will be North Africa (lato sensu) and Africa South of the Sahara-West, Equatorial, Central, and East Africa, and Madagascar. It will be concerned with French-speaking research workers and will deal mainly with the disciplines treated within the XX section of CNRS, but extending also to other 'Sciences de l'homme'.

The documentation includes a catalogue of research workers, comprising some 1,300 names, based on information obtained from a questionnaire sent out in 1963-4; a list of institutions and universities in Africa, Belgium, France, and Switzerland, where teaching in African studies is available; a list of research projects and work in progress, including theses and works not yet published; a list of field expeditions recently completed, in progress and proposed, initiated in Europe (e.g. CNRS, Unesco, FAO, \&c.) and in Africa. The centre also intends to list conferences, seminats, exhibitions, showings of ethnographic films, \&c. These catalogues and lists may be consulted at the centre (Musée de l'Homme, $4^{\mathrm{e}}$ étage, Tél. PASsy $74-46$ and 57-78), or a stamped addressed envelope may be sent for the information required.

The Bulletin itself contains a section on teaching in African Studies $1963-4$, listed under the names of the instructors, and a first list of over 100 research workers and teachers.

\section{African Studies in the Soviet Union}

RESEARCH in the various fields of African studies in the U.S.S.R. is organized within the framework of the Academy of Sciences and carried out in a number of the institutes under its authority. The main relevant branches of the Academy are those of History and of Economics. Within the former are the long-established Institutes of Ethnography in Moscow and in Leningrad. The African section of the Leningrad Institute, under the direction of Professor D. A. Ol'derogge, has been the main centre for ethnographic, historical, and linguistic studies and has the main museum collections. At present it has a senior staff of about ten researchers, together with a similar number of assistants, who are severally engaged in studies on the material culture and ethno-history of the Congo Basin, Arabian sources for the history of East Africa and of the Western Sudan, classical and early European sources on African history, linguistic studies of Swahili, Zulu, Hausa, Fulani, and Mandinka. Two members of the staff are concerned with African archaeology. Some research workers at the Institute of Ethnography in Moscow are associated with the African section of the Leningrad Institute.

In 1960 an Africa Institute was established in Moscow under the auspices of the Economic and Political Sciences branch of the Academy under the direction of Professor I. I. Potekhin, who had earlier formed an African research group in the Moscow Institute of Ethnography. This Institute has been mainly concerned with the colonial period in Africa and with contemporary social, political, and economic studies. Dr. V. G. Solodovnikov, formerly vicedirector of the Institute of World Economy and International Relations, has recently succeeded Professor Potekhin, news of whose death in September I964, following a period of grave illness, has, been received with regret. The Institute has a staff of nine senior research workers and overt wenty more junior assistants. The wide scope of its work is indicated by announcements of recent and prospective publications which include studies on the partition 
of the Congo Basin; French colonial expansion; modern political developments in Nigeria, Guinea, Mali, Tanganyika, Madagascar, and Uganda; economic and social problems of independent African countries; agrarian questions and workers' movements in tropical Africa; religious cults in tropical Africa; ethnographies of Nigeria and of Ethiopia; the Guinea slave trade and ancient Axum.

A two-volume encyclopedia, Afrika, has been published and a two-volume series ' Essays in recent and contemporary African history' is in preparation. An account of the work of the Moscow Institute has recently been contributed to the International Social Science Journal, vol. xvi, 1964, Pp. $431-3$.

University teaching of subjects in the field of African studies is organized independently of the institutes but some of the courses are given by members of their staffs.

\section{Notices in Soviet Journals on the Occasion of the Sixtieth Birthdays of Professors Ol'derogge and Potekhin}

Narody Azii i Afriki and Sovietskaya etnografiya have published notices of the careers of Professors Ol'derogge and Potekhin, from which the following accounts have been translated with acknowledgements.

D. A. Ol'derogge, Professor and Head of the Faculty of African Studies at the University of Leningrad, and Corresponding Member of the USSR Academy of Sciences, was born in 1903, fought as a youth in the Red Army in 1920-2, and studied in the ethno-linguistic faculty of Petrograd University under Professors U. V. Struve, V. Barthold, and N. D. Flitner.

On graduating he was appointed assistant in the Africa section of the Museum of Ethnography and Lecturer in the University in 1929. He defended his doctorate thesis (on the Gens Triplex system) in 1935. From 1934, in addition to his ethnographic lectures, he began teaching Hausa and Swahili at the Institute of Oriental Studies in Leningrad. A separate Faculty of African linguistic and ethnographic studies was created in the University in 1945, which Profesor $\mathrm{Ol}^{\prime}$ derogge has directed since its inception. His publications, from 1928 to date, cover lineage structure and kinship studies, language studies, notably Hausa, Arabic, Amharic, and Bantu languages, and studies in the pre-colonial history of the Sudan belt. Among his major works are: Benin Antiquities (1953, 1955, 1957); The Western Sudan in Isth to 19th centuries (1960); and the editorship and introductory sections of Narody Afriki (1954) and of Arabic Sources from 7 th to roth centuries on Africa South of the Sahara (1960). He is at present directing work on a series of dictionaries of African languages from and into Russian. His field studies include work in Egypt, Senegal, and Mali. Professor Ol'derogge is a member of several international learned bodies, including the Royal Anthropological Institute.

I. I. Potekhin, Professor and Director of the Africa Institute, Academy of Sciences, Moscow, was born in 1903, fought in the Red Army in Siberia, joined the Komsomol in 1920 and the C.P. in 1922. He studied at the Krasnoyarsk Party School and worked in party education until 1929, when he was again called up for army service (on the Chinese railway) until 1930 . On demobilization he combined study in the reconstituted Africa section of the Oriental Institute in Leningrad with organization work. In 1939 he was recalled to the army during the war with Finland, and in this period completed his doctoral thesis on Agriculcultural Organization among the Eastern Bantu. During the war Dr. Potekhin taught MarxismLeninism in the Higher Educational School for Officers. On demobilization in 1946 he turned wholly to academic work at the Institute of Ethnography of the Academy of Sciences in Moscow where he was deputy-director 1949-59. In that year the Africa Institute of the Academy of Sciences was constituted, and Professor Potekhin became its first Director, a post which he held until his death in 1964 . His publications began in 1932 with articles 